VOL. 3

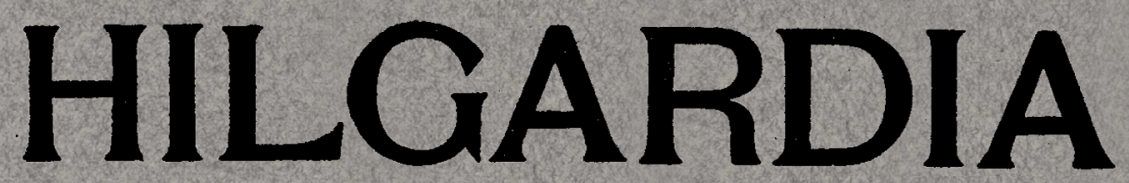

A Journal of Agricultural Science

PUBLISHED BY THE

California Agricultural Experiment Station

CONTENTS

Factors Affecting the Price of Watermelons

at Los Angeles

AND

Factors Affecting the Price of Gravenstein Apples at Sebastopol

EMIL, RAUCHENSTEIN

UNIVERSITY OF CALIFORNIA PRINTING OFFICE BERKELEY, CALIFORNIA 


\section{EDITORIAL BOARD}

E. D. MERRILL, Sc.D.

J. T. Barrett, Ph.D.

Plant Pathology

F. T. Bioletti, M.S.

Viticulture

W. H. Chandler, Ph.D.

Pomology

R. E. Clausen, Ph.D.

Genetics

H. E. Erdman, Ph.D. Agricultural Economics

H. M. Evans, A.B., M.D. Nutrition

G. H. Hart, M. D., D.V.M. Animal Husbandry

D. R. Hoagland, M.S.

Plant Nutrition

A. H. Hoffman, E.E. Agricultural Engineering
W. L. Howard, Ph. D.

Pomology

H. A. Jones, Ph.D.

Truck Crops

W. P. Kelley, Ph.D.

Chemistry

W. A. Lippincott, Ph. D.

Poultry Husbandry

C. S. Mudge, Ph. D.

Bacteriology

H. J. Quayle, M.S.

Entomology

H. S. Reed, Ph. D.

Plant Physiology

W. W. Robbins, Ph. D.

Botany

F. J. Veihmeyer, Ph. D.

Irrigation 


\title{
FACTORS AFFECTING THE PRICE OF GRAVENSTEIN APPLES AT SEBASTOPOL
}

\author{
EMIL RAUCHENSTEIN1
}

\section{THE PROBLEM}

Early in 1927 the Gravenstein apple growers in the Sebastopol district organized partly for the purpose of strengthening their bargaining position with buyers in determining the price which they should receive for their apples. This brings up the problem of estimating, at the beginning of the season, the price which will equate supply and demand under the conditions prevailing that season.

While it is generally known that a large crop usually brings a low price per box, and a small crop usually brings a high price, no schedule has been worked out up to this time, on the basis of the average relationship that has prevailed between supply and price, showing the price which crops of various sizes have brought; and no study has been made of the effect on prices of other factors than the supply of Gravensteins in the Sebastopol district. It is the purpose of this paper to present and analyze the data available on this problem in order to determine the important factors that have affected prices in the past, and to show how the results may be used, as a starting point at least, for estimating a fair price at the beginning of the season under a given set of conditions.

\section{DATA AVAILABLE}

Records of Gravenstein apple production in the Sebastopol district and prices received by farmers at the packing plants are available from 1912 to date, and are shown in table 1 and figure 1. Table 1 also gives the all-commodity index number for July of each year, which gives a fairly good measure of the changing value of the dollar. By dividing the price for each year by the July index number of that year and multiplying the quotient by 1.50 the adjusted price

\footnotetext{
1 Associate in Agricultural Economics.
} 
series, shown in column $X$, is obtained. This shows the prices approximately as they would have been if the dollar had had the same purchasing power during the whole period as it had during 1927. The prices referred to hereafter in this paper are these adjusted prices.

The estimates (July 1 and final) of total United States apple production are also shown in table 1 and the July 1 estimates in figure 1.

\section{TABLE 1}

Apple Production Estimates of July 1 and Final Estimates for the United States, Gravenstein Apple Production in the Sebastopol District, and Gravenstein Apple Prices, 1912-1927

\begin{tabular}{|c|c|c|c|c|c|c|}
\hline \multirow[b]{2}{*}{ Year } & \multicolumn{2}{|c|}{ United States production } & \multirow{2}{*}{$\begin{array}{c}\text { Gravenstein } \\
\text { apple } \\
\text { production } \\
\text { in Sebastopol } \\
\text { district } \\
\text { (Thousands of } \\
\text { boxes) } \\
B\end{array}$} & \multirow{2}{*}{$\begin{array}{c}\text { Price of } \\
\text { Gravensteins } \\
\text { per box } \\
\text { to farmers } \\
\text { at packing } \\
\text { plants } \dagger\end{array}$} & \multirow[b]{2}{*}{$\begin{array}{c}\text { July } \\
\text { index } \ddagger \\
\text { numbers } \\
\text { (all } \\
\text { commodity) }\end{array}$} & \multirow[b]{2}{*}{$\begin{array}{c}\text { Price } \\
\text { adjustec } \\
\text { to } 1927 \\
\text { price } \\
\text { level } \\
X\end{array}$} \\
\hline & $\begin{array}{c}\text { Estimates } \\
\text { of July } 1 \\
\text { (Millions of } \\
\text { bushels) } \\
A\end{array}$ & $\begin{array}{c}\text { Final }^{*} \\
\text { Estimates } \\
\text { (Millions of } \\
\text { bushels) }\end{array}$ & & & & \\
\hline 1912 & 228 & 235 & 53 & $\$ 0.54$ & 101 & $\$ 0.80$ \\
\hline 1913 & 209 & 145 & 42 & 0.98 & 102 & 1.44 \\
\hline 1914 & 210 & 253 & 77 & 0.46 & 99 & 0.71 \\
\hline 1915 & 194 & 230 & 80 & 0.52 & 102 & 0.77 \\
\hline 1916 & 219 & 194 & 96 & 0.61 & 125 & 0.74 \\
\hline 1917 & 200 & 167 & 152 & 0.93 & 191 & 0.74 \\
\hline 1918 & 195 & 170 & 194 & 1.43 & 200 & 1.06 \\
\hline 1919 & 156 & 142 & 322 & 1.98 & 216 & 1.38 \\
\hline 1920 & 200 & 224 & 400 & 1.73 & 245 & 1.05 \\
\hline 1921 & 102 & 99 & 367 & 1.72 & 144 & 1.79 \\
\hline 1922 & 190 & 203 & 714 & 0.47 & 158 & 0.45 \\
\hline 1923 & 189 & 203 & 1,172 & 0.73 & 153 & 0.72 \\
\hline 1924 & 196 & 172 & 563 & 1.15 & 150 & 1.15 \\
\hline 1925 & 179 & 172 & 126 & 1.96 & 163 & 1.80 \\
\hline 1926 & 208 & 246 & 1,134 & 0.39 & 153 & 0.39 \\
\hline 1927 & 137 & 123 & 680 & 1.66 & 147 & 1.70 \\
\hline
\end{tabular}

Column $A$, data obtained from July numbers of Crops and Markets Monthly Supplement and official series of U. S. Dept. Agr. preceding Crops and Markets.

* From U. S. Dept. Agr. Yearbook 1926: 896, 1927; except for 1927 which is from Crops and Markets 4 (12): 453.1927.

Column $B$, data obtained from representative shippers by H. F. Gould and L. W. Fluharty.

† Data obtained by L. W. Fluharty from representative shippers. Average of Fancy 4 and $41 / 2$ tier.

$\ddagger$ Bureau of Labor Statistics index number converted to 1910-1914 base. U. S. Dept. Agr. Supplement to Agriculture Situation June 1927, and current issues.

\section{Analysis of Data}

General Analysis.-Having eliminated the effect of the changing value of the dollar on prices, it is possible from a close study of figure 1 and table 1 to find some evidence of consistent inverse correlation between production and price (adjusted). Thus from 1912 to 1913 there was a decrease in the July 1 estimate of United States 
production associated with a considerable increase in the price of Gravenstein apples. Again there was a decrease in production estimates in each of the years 1917, 1918, and 1919 associated with consistent increases in price. The years 1920, 1921, and 1922 are also good examples of this inverse correlation.

Comparison of Gravenstein Apple Prices with Production in Sebastopol District and July 1 Estimates of Total United States Apple Production

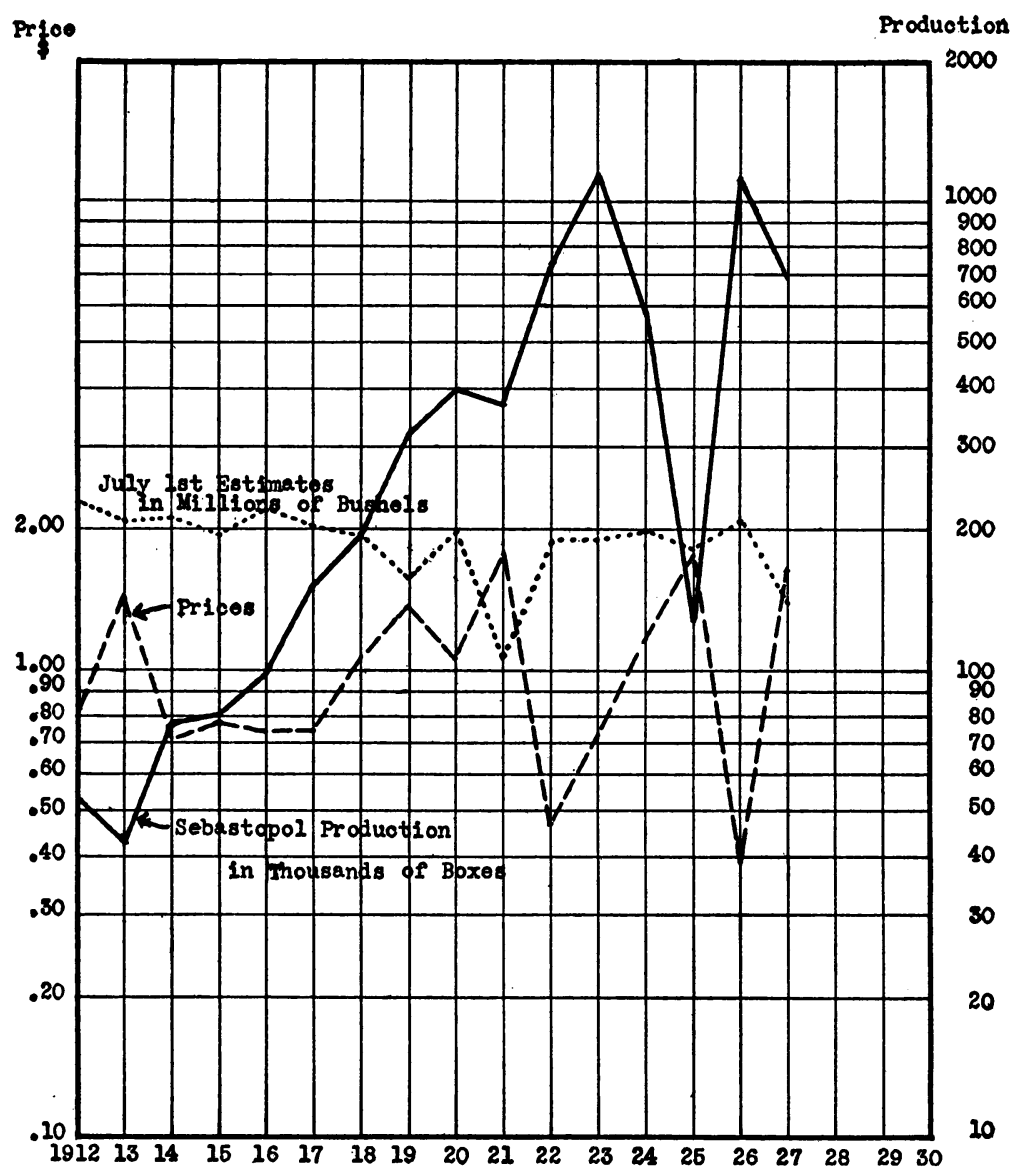

Fig. 1. The inverse correlation between Gravenstein apple production and price in the Sebastopol district is not at all marked until about 1919. Since then it has been noticeable. July 1 estimates of United States production also shows an inverse correlation with Gravenstein prices.

(Data from table 1.) 
The inverse correlation between Gravenstein apple production in the Sebastopol district and prices from 1912 to 1918 is not evident, except for the first two years. When one notes the low production of Gravenstein apples-no year above 100,000 boxes during the first five years covered by this study-it becomes evident that they were such a small factor in the market during these years that they would not affect prices to an appreciable extent. The rapid increase in production after 1916 is shown by the fact that although up to that time production was never above 100,000 boxes a year, eight years later (in 1923) the production exceeded 1,000,000 boxes. During several years since 1920, California apple shipments in July which consist mainly of Gravensteins from the Sebastopol district, amounted to one-third of the total United States apple shipments for that month (see table 3).

Beginning with 1919 there is a noticeable inverse correlation between Gravenstein apple production and price. With the exception of 1923 the price changes from the previous years were in the opposite direction from the production. The amount of change in price, however, is apparently affected by both Gravenstein production in the Sebastopol district and United States production. The drop in price from $\$ 1.38$ to $\$ 1.05$ from 1919 to 1920 was probably eaused only in part by the increase in Gravensteins from 322,000 to 400,000 boxes, and in part by the increase in United States production (July 1 estimates) of $156,000,000$ to $200,000,000$ bushels. The increase in price in 1921 to $\$ 1.79$ again was probably due in part to the slight drop in Gravenstein production, but more largely to the big drop (from 200,000,000 to 102,000,000 bushels) in United States production. From 1918 to 1919 Gravenstein production at Sebastopol went up while United States production went down. The latter factor seemed to exert the greater influence since the price of Gravensteins went up.

Correlation Analysis. ${ }^{2}$ - The degree of relationship between two variables can be determined with considerable accuracy by means of the correlation coefficient. The final estimates of apple production in the United States from 1919 to 1927 and prices of Gravensteins show a correlation coefficient of -0.80 . However, if growers are to have any basis for estimating the price which Gravenstein apples should bring, data must be used which become available before the

2 The method used in these calculations is described in detail in the publication by Wallace, H. A., and Geo. W. Snedecor. Correlation and machine calculation. Iowa State College of Agr. and Mechanic Arts, Official Publication 23:1-47. 1925. 
crop is sold. Since the crop is usually shipped during July and the first part of August, the July 1 estimate of total apple production should give the best indication of the probable effect of production in the country as a whole.

The estimates of July 1 were not as close to the final production during the first years of the period as they were later, although even from 1914 to 1927 the correlation coefficient between them and Gravenstein prices is -0.77 .

A study of the other factor (production of Gravensteins in the Sebastopol district) clearly shows some association with prices during recent years. Some difficulties are involved, however, in evaluating its effect for the whole period, because of the rapid increase in production from less than 100,000 boxes in 1912 to more than 1,000,000 boxes in 1923 and 1926. Disregarding trend in production the correlation coefficient between Gravenstein apple production in the Sebastopol district and price was -0.2602 for the period 1912 to 1927 , and -0.2616 for the period 1914 to 1927 . Obviously these correlation coefficients do not show the true relationship for the later years because of the irregular upward trend in production, and further the effect has probably been increasing relative to the effect of total United States production. ${ }^{3}$

A multiple regression equation based on the period 1914 to 1927 for estimating prices from July 1 estimates of United States production and Gravenstein production in the Sebastopol district would probably overemphasize the effect of the latter.

In order to compare possible changes in the regression equation for various periods the necessary calculations were made based on the relationships between the three factors for the period 1914-1927. The resulting equation was $\bar{X}=3.3741-0.01179 A-0.000402 B$, in which $\bar{X}$ represents estimated price in dollars, $A$, July 1 estimates of United States production, and $B$, Gravenstein production in the Sebastopol district. The multiple correlation coefficient $\left(R_{X . A B}\right)$ was equal to 0.8298 , the standard error of estimate $\left(S_{X . A B}\right)$ was 0.256 , and the coefficients of determination indicated that approximately 61 per cent of the variations in price were due to United States production and 8 per cent to Sebastopol production of Gravensteins. Price estimates for the period 1914-1927 based on the above equation fall within $\$ 0.25$ of the actual price ten out of the fourteen years.

\footnotetext{
3 By correlating first differences of logarithms of production and prices a correlation index of -0.54 is obtained. This method does away with the difficulty of the production trend, but cannot show whether or not the relationship is becoming closer toward the end of the period.
} 
Correlation of Production and Price from 1919 to 1927.-Figure 1 shows that Gravenstein apple production in the Sebastopol district increased very rapidly from 1913 to 1919 . Since 1919 the trend upward has been much less pronounced and in one year (1925) the production was below that of 1919. An analysis of the average relationships that have prevailed between production and price during the later period therefore should give results more applicable to the problem of estimating the price that will move the 1928 and 1929 crops, than the results based on the average relationship for the whole period 1912 to 1927 , in spite of the fact that only nine years are included in the later period. The correlations for the later period are in line with what one would logically expect. That is, since 1919 the Sebastopol crop of Gravensteins has become a more important factor on the markets in July and August than it was previous to 1919, and therefore its effect on Gravenstein apple prices during the later period has been much more marked than it was for the earlier period. This is brought out by the coefficients of determination, which indicate that for the period 1919 to $1927,40.7$ per cent of the variations from year to year in Gravenstein apple prices were associated with variations in production of Gravensteins in the Sebastopol district, compared with 8.0 per cent for the period 1914 to 1927 ; and 38.5 per cent were associated with variations in the July 1 estimates of total United States production in the later part of the period, compared with 61.0 per cent for the whole period.

Table 2 and figure 2 show the actual and estimated prices of Gravenstein apples. The estimated prices are based on the average relationship of actual prices and the production data noted above for the period 1919 to 1927 . This period, of course, is too short to constitute a very reliable statistical sample, but the results bear out the logical expectations.

The residuals (actual prices minus estimated) in table 2 are $\$ 0.17$ or less in six years out of the nine. The extremely low price of 1922 may have been caused in part by the railroad strike at the time Gravensteins were being shipped. ${ }^{4}$ In 1925 the actual price was $\$ 0.29$ above the estimated price. Apparently the extremely short crop $(126,000$ boxes $)$ in the Sebastopol district exerted more than a proportional upward pull on the price. In 1927 the actual price again exceeded the estimated, this time by $\$ 0.30$. Possibly the organization of growers in 1927 which quoted a uniform price to buyers may have strengthened their bargaining power to the extent of $\$ 0.30$ a box.

4 This suggestion was made by Mr. G. E. Burlingame, secretary of the Sebastopol Chamber of Commerce. 
June, 1928] Rauchenstein: The Price of Gravenstein Apples at Sebastopol 331

TABLE 2

Actual and Estimated Prices of Gravenstein Apples, 1919-1927

\begin{tabular}{c|c|c|c}
\hline \hline Year & $\begin{array}{c}\text { Actual } \\
\text { adjusted price } \\
X\end{array}$ & $\begin{array}{c}\text { Estimated } \\
\text { price } \\
X\end{array}$ & $\begin{array}{c}\text { Residuals } \\
Z\end{array}$ \\
\hline 1919 & $\$ 1.38$ & $\$ 1.54$ & $\$-0.16$ \\
1920 & 1.05 & 1.11 & -0.06 \\
1921 & 1.79 & 1.95 & -0.16 \\
1922 & 0.45 & 0.93 & -0.48 \\
1923 & 0.72 & 0.55 & +0.17 \\
1924 & 1.15 & 1.01 & +0.14 \\
1925 & 1.80 & 1.51 & +0.29 \\
1926 & 0.39 & 0.43 & -0.04 \\
1927 & 1.70 & 1.40 & +0.30 \\
\hline
\end{tabular}

Column $\bar{X}$ calculated from the equation $\bar{X}=3.10901-0.00832 A-0.000839 B$.

Residuals $Z$ equal actual minus estimated prices.

Actual and Estimated Farm Prices of Gravenstein Apples

$0+100$

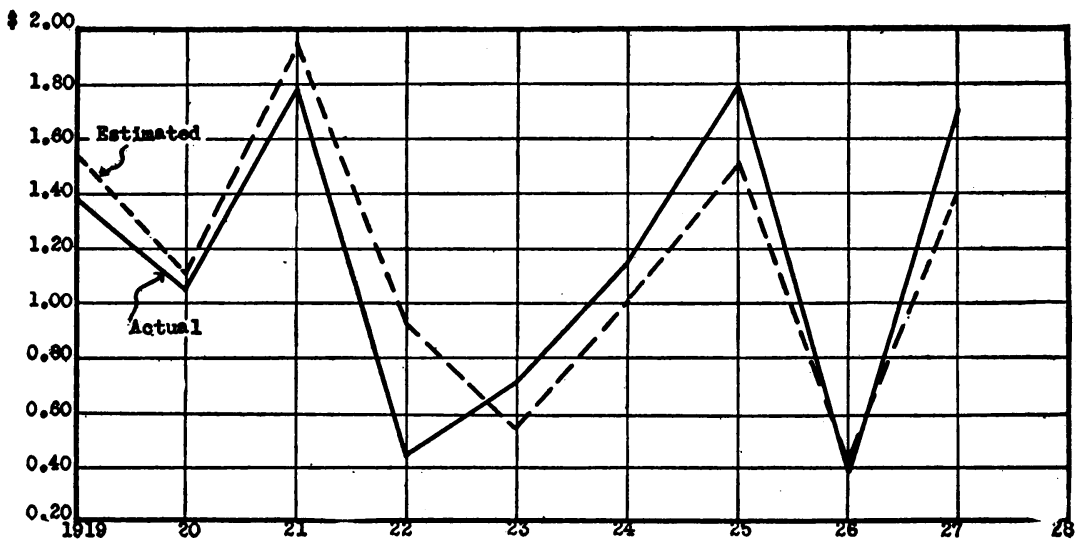

Fig. 2. Estimates of Gravenstein apple prices based on the average relationship between prices, July 1 estimates of United States production, and Gravenstein production in the Sebastopol district come within $\$ 0.17$ of the actual price six years out of nine.

(Data from table 2.)

Possible Causal Relationships Involved in the Determination of Gravenstein Apple Prices.-The fact that there is a high degree of association between two variables does not prove that one is necessarily the antecedent or cause of the other. In the case of Gravenstein apple production in the Sebastopol district and prices of Gravensteins at Sebastopol, it seems clear that high production would cause low prices (other things remaining the same) and low production 
would cause high prices. The correlation coefficient between these two variables from 1919 to 1927 was - 0.749, which may be considered as representing a cause and effect relationship. With July 1 estimates of total United States production and Gravenstein apple prices, the cause and effect relationship is not so self evident. Are buyers influenced by the supply coming onto the markets in July and early August, or by their anticipation of the size of the total crop? Probably both factors affect the price. Table 3 and figure 3

TABLE 3

Total Apple Shipments in the United States and from California for July and August, and Farm Prices of Gravenstein

Apples at SebastopoL, 1919-1927

\begin{tabular}{|c|c|c|c|c|c|}
\hline \multirow[b]{2}{*}{ Year } & \multicolumn{2}{|c|}{ July shipments } & \multicolumn{2}{|c|}{ August shipments } & \multirow{2}{*}{$\begin{array}{c}\text { Prices } \\
\text { (adjusted) } \\
\text { to farmers at } \\
\text { Sebastopol }\end{array}$} \\
\hline & $\begin{array}{c}\text { Total } \\
\text { United States } \\
\text { carlots }\end{array}$ & $\begin{array}{l}\text { California } \\
\text { carlots }\end{array}$ & $\begin{array}{c}\text { Total } \\
\text { United States } \\
\text { carlots }\end{array}$ & $\begin{array}{l}\text { California } \\
\text { carlots }\end{array}$ & \\
\hline 1919 & 1,347 & 273 & 2,712 & 441 & $\$ 1.38$ \\
\hline 1920 & 1,855 & 244 & 3,861 & 723 & 1.05 \\
\hline 1921 & 1,207 & 352 & 3,384 & 690 & 1.79 \\
\hline 1922 & 2,592 & 220 & 4,923 & 998 & 0.45 \\
\hline 1923 & 3,360 & 1,290 & 4,122 & 984 & 0.72 \\
\hline 1924 & 2,362 & 729 & 3,126 & 645 & 1.15 \\
\hline 1925 & 2,895 & 341 & 4,330 & 155 & 1.80 \\
\hline 1926 & 3,665 & 1,480 & 3,131 & 591 & 0.39 \\
\hline 1927 & 1,731 & 289 & 3,352 & 841 & 1.70 \\
\hline
\end{tabular}

Prices from Table 1.

Shipments for 1919-1922 compiled from U. S. Dept. Agr. Statis. Bul. 7:2-5; for 1923-1926 from Monthly Supplement of Crops and Markets $3(8,9)$ 1926; for 1927 from Monthly Supplement of Crops and Markets $4(8,9), 1927$.

show apple shipments in July and August in the United States, California apple shipments in July, and the price of Gravensteins at Sebastopol. In general, low July shipments were associated with high prices, and high shipments with low prices. The year 1923 seems to be an exception since the price and shipment changes from 1922 are both upward. This may be due to the railroad strike in 1922 (mentioned on p. 330) which seems to have depressed the 1922 price much below normal for the production of that year. Compared with other years than 1922, the price in 1923 seems to be normal considering the quantity shipped. The year 1925 is noteworthy in that price and shipments were both higher than in 1921. Gravenstein prices in 1925 seem to have been affected specifically by the short crop of Gravensteins since shipments for the United States as a whole were relatively high, but shipments from California were very low. The 
correlation coefficient between July shipments in the United States and Gravenstein prices for the period 1919 to 1927 was -0.65 , between California apple shipments in July and Gravenstein prices -0.58 , and between July 1 estimates of United States production and Gravenstein prices it was -0.74 .

Apple Shipments in the United States and California and Prices of Gravenstein APPLES

Prico

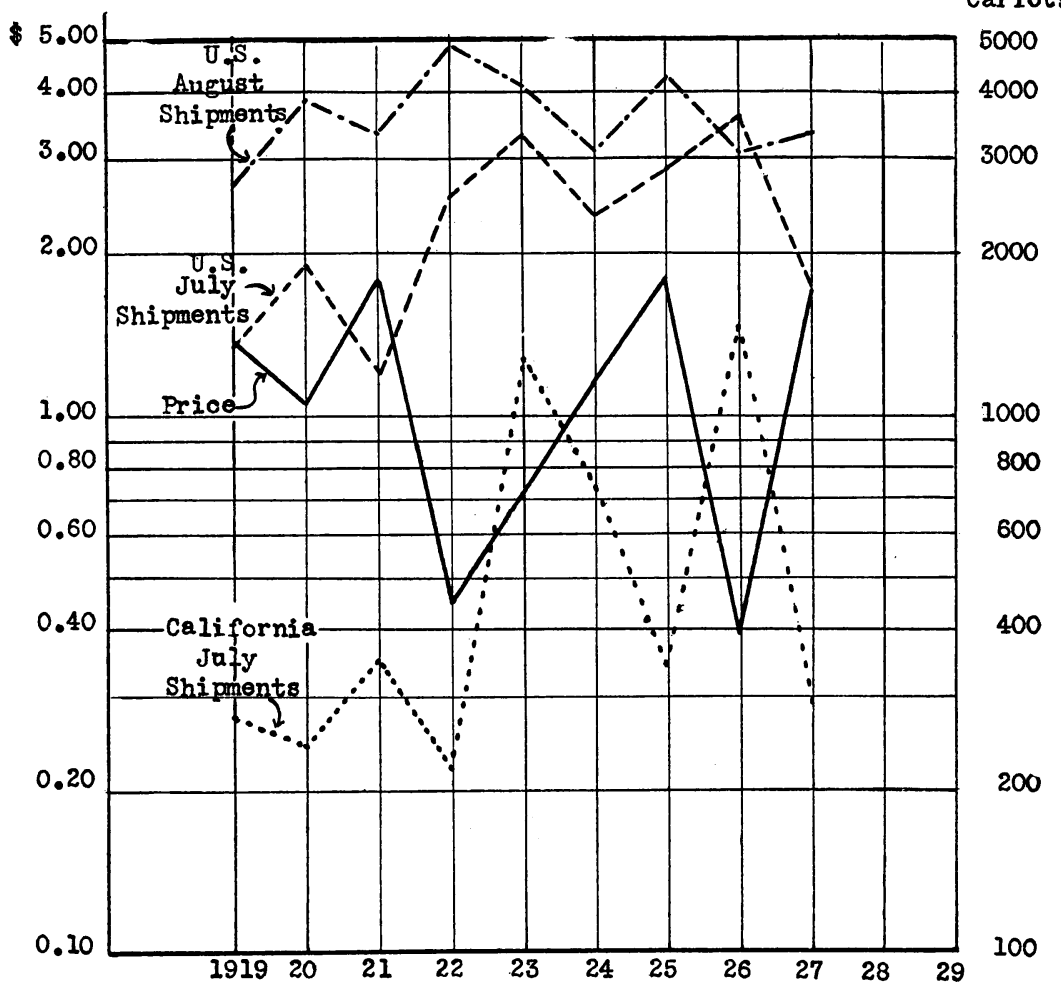

Fig. 3. High apple shipments in the United States in July and low prices for Gravensteins tend to go together and low shipments go with high prices. Since 1923 California shipments in July and Gravenstein prices show a elose inverse correlation.

(Data from table 3.)

August shipments in the United States are not as closely correlated with Gravenstein apple prices as are the July shipments. The correlation coefficient is - 0.3819. This smaller correlation is to be expected because the bulk of the Gravenstein apple crop is usually marketed in July. 
There is a fairly close correlation between July shipments in the United States from 1919 to 1927 and July 1 estimates of United States production. The correlation coefficient is -0.73 . The correlation coefficient between July shipments and final estimates of production is also - 0.73. Probably one reason why the correlation between July apple shipments in the United States and Gravenstein apple prices is not closer than the correlation of July 1 estimates of United States production and prices is that July shipments vary from year to year, partly as the result of variations in the size of the total crop, and partly as the result of the time of ripening. If accurate data could be obtained as to the total quantities of apples coming onto the markets during the period in which Gravenstein apples are marketed, they would probably show a higher correlation coefficient with price than that obtained between July 1 estimates and price.

The practical conclusion to be drawn from these correlation studies is that the July 1 estimates of United States production are the best figures to use in estimating the effect of the country's total apple production on the price of Gravenstein apples because they probably indicate fairly accurately the competition which Gravenstein apples will have during the following six or eight weeks with apples from other parts of the United States.

\section{HOW TO USE THE RESULTS OF THE PRICE ANALYSIS}

The average relationship between July 1 estimates of United States apple production $(A)$, Gravenstein apple production in the Sebastopol district $(B)$, and the price of Gravensteins $(X)$, for the period 1919 to 1927 , is expressed in the formula

$$
\bar{X}=3.10901-0.00832 A-0.000839 B,
$$

in which $A$ is in millions of bushels, $B$ in thousands of boxes, and $\bar{X}$ in dollars per box. This equation indicates that for the period 1919 to 1927 each change of $1,000,000$ in $A$, the price on an average changed 0.832 cents, and for each change of 1,000 in $B$ the price changed 0.0839 cents-changes in price in each case being in the opposite direction from changes in quantities.

The fact that the relationship expressed by this equation has held somewhat consistently for the past nine years should make it of some value to buyers and sellers of Gravenstein apples in California in deciding on a price for apples which should move them into consumption. 


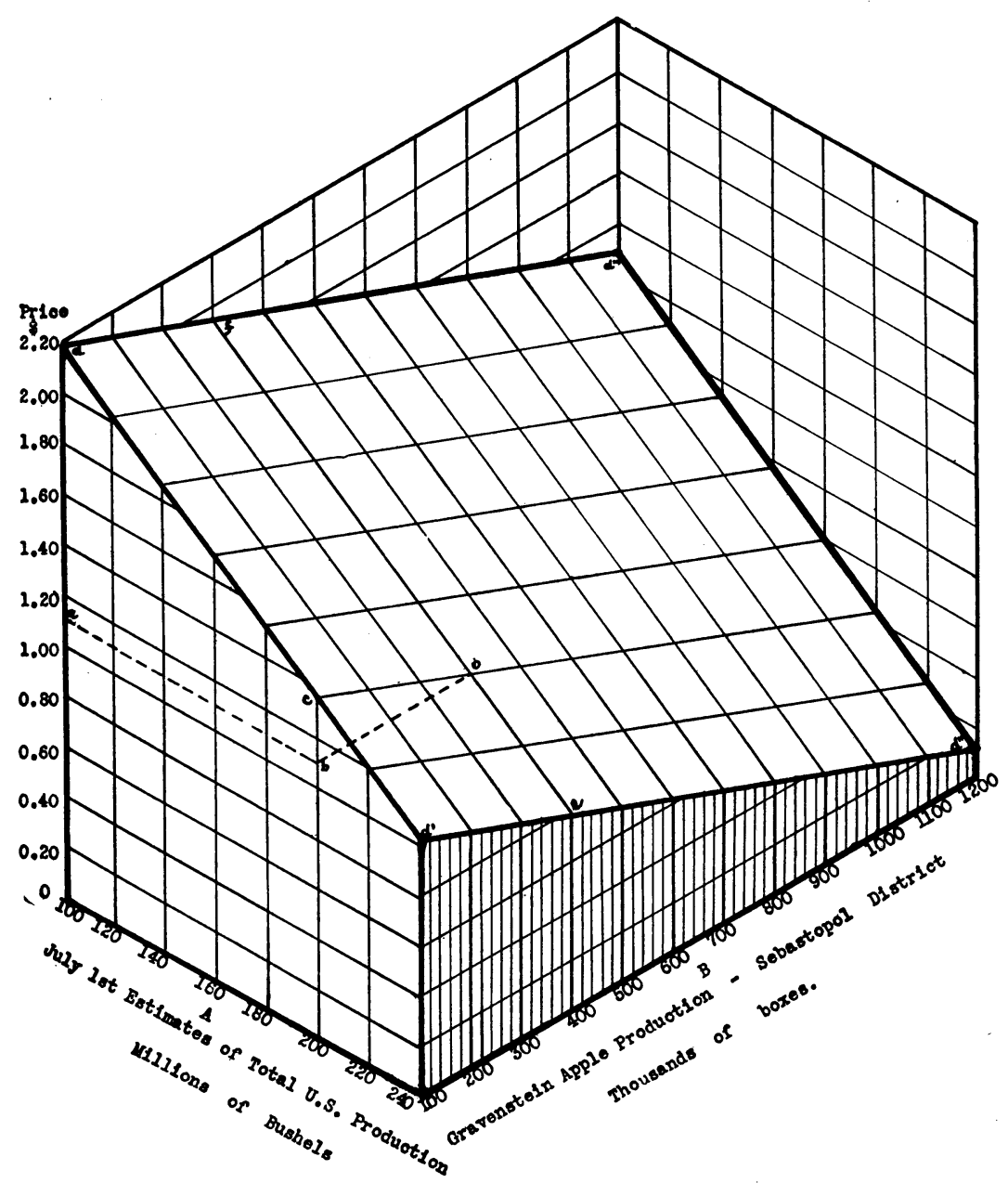

Fig. 4.-The line $d d^{\prime}$ and those parallel to it show the average net effect of July 1 estimates of United States production on Gravenstein apple prices with Gravenstein production held constant at various values along $B$. The line $d d^{\prime \prime \prime}$ and those lines parallel to it show the average net effect of Gravenstein apple production in the Sebastopol district on price with United States production held constant at various values along $A$. 
To illustrate the use of the equation let us assume the following conditions :

$A$-July 1 estimates of United States apple production $=200$ million bushels.

$B$-Sebastopol production of Gravenstein apples $=400$ thousand boxes. (Estimates of the size of the crop in the Sebastopol district can be made very accurately at the beginning of the season.)

The problem is to find $\bar{X}$ - the price to the farmers which, based on past experience, will come closest to equating supply and demand.

Substituting in the equation

$$
\bar{X}=3.10901-0.00832 A-0.000839 B
$$

the above values for $A$ and $B$ we obtain

$$
\begin{aligned}
\bar{X} & =3.10901-(0.00832 \times 200)-(0.000839 \times 400) \\
& =3.10901-1.664-0.3356 \\
& =\$ 1.11
\end{aligned}
$$

The estimated price for any values of $A$ and $B$ within the range shown may also be obtained approximately from figure 4, which shows graphically the average effect of $A$ and $B$ on price from 1919 to 1927 . The line $d d^{\prime}$ in figure 4 shows the average net effect on price of production estimates from 100 million to 240 million bushels with a constant production of 100 thousand boxes for $B$. The next line parallel to $d d^{\prime}$ shows the average net effect on price of production estimates from 100 million to 240 million bushels with a constant production of 200 thousand boxes for $B$. The other lines parallel to $d d^{\prime}$ including $d^{\prime \prime \prime} d^{\prime \prime}$ show the net effect on price of production estimates from 100 to 240 million bushels with constant productions of $300,400,500$, etc., to 1,200 thousand boxes at $d^{\prime \prime \prime} d^{\prime \prime}$.

In the same way the line $d d^{\prime \prime \prime}$ shows the average net effect of varying $B$ from 100 thousand to 1,200 thousand while $A$ is constant at 100 millon. The next line parallel to $d d^{\prime \prime \prime}$ shows the same thing for various values of $B$ with $A$ at 120 millions. The other lines parallel to $d d^{\prime \prime \prime}$ including $d^{\prime} d^{\prime \prime}$ show the net effect on price of various values of $B$ with $A$ at values from 140 to 240 million bushels.

To illustrate the use of figure 4 in estimating the price that will equate supply and demand let us assume a value of 200 million for $A$ and 400 thousand for $B$-the same values used in illustrating the use of the equation above. The line extending from 200 on the base line $A$ to the line $d d^{\prime}$ meets it at $c$, which indicates a price estimate of $\$ 1.36$ with $B$ having a value of 100 thousand. In order 
to get the price estimate when $B$ has a value of 400 thousand, follow the line from $c$ to $o$ parallel to $d^{\prime} d^{\prime \prime}$. At $o$ it intersects the line $e f$ which gives the various price estimates when $B$ equals 400 thousand and $A$ varies from 100 million to 240 million. The point $o$, therefore, is the point which represents the price estimates when $A$ equals 200 million and $B 400$ thousand. In order to read the price represented by $o$, draw a line from $o$ parallel to $B$ until it meets the vertical line extending from 200 to $c$. This intersection occurs at $b$. From $b$ extend a line parallel to $A$ which meets the price scale at $a$ where the reading is $\$ 1.11$.

TABLE 4

Average Relation of July 1 Estimates of United States Production, Gravenstein Production, and Prices of Gravensteins FROM 1919-1927

\begin{tabular}{|c|c|c|c|c|c|c|c|c|}
\hline \multirow{3}{*}{$\begin{array}{l}\text { July } 1 \text { estimates } \\
\text { of United States } \\
\text { production } \\
\text { millions of } \\
\text { bushels }\end{array}$} & \multicolumn{8}{|c|}{ Gravenstein production thousands of boxes } \\
\hline & 100 & 200 & 300 & 400 & 500 & 600 & 700 & 800 \\
\hline & \multicolumn{8}{|c|}{ Prices of Gravensteins, ${ }^{*}$ dollars } \\
\hline 100 & 2.19 & 2.11 & 2.03 & 1.94 & 1.86 & 1.77 & 1.69 & 1.61 \\
\hline 120 & 2.03 & 1.94 & 1.86 & 1.78 & 1.69 & 1.61 & 1.52 & 1.44 \\
\hline 140 & 1.86 & 1.78 & 1.69 & 1.61 & 1.51 & 1.44 & 1.36 & 1.27 \\
\hline 160 & 1.69 & 1.61 & 1.53 & 1.44 & 1.36 & 1.27 & 1.19 & 1.11 \\
\hline 180 & 1.53 & 1.44 & 1.36 & 1.28 & 1.19 & 1.11 & 1.02 & 0.94 \\
\hline 200 & 1.36 & 1.28 & 1.19 & 1.11 & 1.03 & 0.94 & 0.86 & 0.77 \\
\hline 220 & 1.19 & 1.11 & 1.03 & 0.94 & 0.86 & 0.78 & 0.69 & 0.61 \\
\hline 240 & 1.03 & 0.94 & 0.86 & 0.78 & 0.69 & 0.61 & 0.52 & 0.44 \\
\hline
\end{tabular}

* Based on the regression equation $\bar{X}=3.10901-0.00832 A-0.000839 B$.

The price estimates that will be obtained at the intersection of the various lines on the plane $d d^{\prime} d^{\prime \prime} d^{\prime \prime \prime}$ of figure 4 are shown in table 4. Thus when $A$ equals 200 and $B$ equals 400 the price estimate $\$ 1.11$ is found at the intersection of the line of price estimates having 200 on the left and the column of price estimates having 400 above. It is interesting to note that a change of 20 in $A$ has approximately the same effect on the estimated price as a change of 200 in $B$. For example, values of 100 for $A$ and 300 for $B$ give the same estimated price of $\$ 2.03$ as values of 120 for $A$ and 100 for $B$. This, of course, is also apparent from the equation $\bar{X}=3.10901-0.00832 A$ $-0.000839 B$. For intermediate values of $A$ and $B$, such as 185 for $A$ and 740 for $B$, close estimates can be made from either figure 4 or table 4 . 


\section{SUMMARY}

The price of Gravenstein apples at Sebastopol is affected by the size of the Gravenstein crop in that district, and by the size of the total apple crop in the United States. The relative effect of the former has been increasing with the increase in the size of the crop since 1912, and the effect of the latter has been decreasing.

The extent of the competition which Sebastopol Gravenstein apples are likely to meet from the rest of the United States is indicated to some extent at the beginning of the season by the July 1 estimates of United States production which are closely correlated with July shipments of apples. From 1919 to 1927 approximately 38.5 per cent of the variations in Gravenstein prices are accounted for by variations in July 1 estimates of United States production, and 40.7 per cent of the price variations are accounted for by variations in Gravenstein production in the Sebastopol district.

The average relationship from 1919 to 1927, between price and the important factors that have been found to affect price, is shown by the equation

$$
\bar{X}=3.10901-0.00832 A-0.000839 B
$$

in which $\bar{X}$ represents estimated price, $A$ represents July 1 estimates of United States apple production in millions of bushels, and $B$ represents Gravenstein apple production in the Sebastopol District in thousands of boxes. Table 4, page 337, has been prepared by substituting the various production figures in the above equation and solving for $\bar{X}$-the price, judging from past experience, that is most likely to equate supply and demand for each combination of production figures. An understaning of the relationships that have prevailed in the past should be of value to any organization of Gravenstein apple growers in the Sebastopol district that wishes to have some basis for estimating at the beginning of the season, the price which is likely to bring about this equilibrium between supply and demand.

\section{ACKNOWLEDGMENTS}

The writer is indebted to L. W. Fluharty, extension specialist in farm management, for first noting the relationship between total apple production in the United States and the farm price of Gravensteins at Sebastopol.

$\mathrm{He}$ is also indebted to George L. Horenstein, student assistant, for help in the statistical computations. 
The titiles of the Technical Papers of the Callfornia Agricultural Isperiment Station, Nos. 1 to 20, which III.GARDIA replaces, and copies of which may be had on application to the Publication Secretary, Agrlcultural Ixperimemt Station, Berkeley, are as follows:

1. The Removal of Sodium Carbonate from Solls, by Walter $P$. Kelley and Fidward E. Thomas. January, 1923.

3. The Formation of Sodium Carbonate in Soils, by Arthur B. Oummins and Walter P. Kelley. March, 1923.

4. Effect of Sodium Chlorid and Calcium Ohlorid upon the Growth and Oomposition of Yowng Orange Irees, by II. S. Reed and A. R. O. ILas, April, 1923.

B. Citrus Blast and Black Pit, by H. S. Fawcett, W. T. Frome, and A. I. Camp. May, 1923.

6. A Study of Deciduous Iruit Tree Rootstocks with Special Reference to Their Identification, by Myer J. Heppner. June, 1923.

7. A Study of the Darkening of Apple Iissue, by I. I. Overholser and W. $\nabla$. Cruess. Jume, 1923.

8. Fffect of Salts on the Intake of Inorganic Blements and on the Buffer System of the Plant, by D. R. Hoagland and J. C. Martin. July, 1923.

9. Expeximents on the Reclamation of Alkall Solls by Leaching with Water and Gypsum, by P. I. Tuibbard. August, 1923.

10. The Seasonal Variation of the Soil Moisture in a Walnut Grove In Relation to Hygroscopic Coefficient, by I. D. Batchelor and F. B. Reed. September, 1923.

11. Studies on the Fffects of Sodium, Potassium, and Calcium on Young Orange Trees, by II. S. Reed and A. R. C. Haas. October, 1923.

12. The Fffect of the Plant on the Reaction of the Culture Solution, by D. R. Hoagland. November, 1923.

18. Some Mutual Effects on Soll and Plant Induced by Added Solutes, by John S. Burd and J. O. Martin. December, 1923.

14. The Respiration of Potato Tubers in Relation to the Occurrence of Blackheart, by J. P. Bennett and B. T. Bartholomew. January, 1924.

15. Replaceable Bases in Solls, by Walter P. Kelley and 8. Melvin Brown. Tebruary, 1924.

16. The Moisture Fquivalent as Influenced by the Amount of Soll Used in its Determination, by $I$. J. Velhmeyer, 0 . W. Israelsen and J. P. Conrad. Soptomber, 1924.

17. Nutrient and Toxic Effects of Certaln Ions on Citrus and Wainnt Trees with Fspecial Reference to the Concentration and Ph of the Medium, by II. S. Roed and A. R. C. Haas, October, 1924.

18. Factors Influencing the Rate of Germination of Eeed of Asparagus offichnalis, by H. A. Borthwick. March, 1925.

10. The Relation of the Subcutaneous Administration of Iiving Bacterium abortum to the Immunity and Carrier Problem of Bovine Infectious Abortion, by George H. Hart and Jacob Trawm. April, 1925.

20. A Study of the Conductive Iissues in shoots of the Bartiett Pear and the Relationship of Food Movement to Dominance of the Apical Buds, by Frank Ir. Gardner. April, 1925. 